\title{
Identification of Major Crop Production Constraints and Technology Needs in H1 Agro-ecology of Alga PA in South Ari District of South Omo Zone
}

\author{
Misgana Mitiku ${ }^{1}$, *, Mehari G/michael ${ }^{1}$, Tamirat Gutema ${ }^{1}$, Awoke Tadesse ${ }^{1}$, Wondimu Adila ${ }^{1}$, \\ Wondewosen Shiferaw ${ }^{1}$, Geremew Biramo ${ }^{2}$ \\ ${ }^{1}$ Southern Agricultural Research Institute, Jinka Agricultural Research Center, Jinka, Ethiopia \\ ${ }^{2}$ Southern Agricultural Research Institute, Arba Minch Agricultural Research Center, Arba Minch, Ethiopia
}

\section{Email address:}

misganamitiku441@gmail.com (M. Mitiku),mehari1999@yahoo.com (M. G/Michael)gutame2007@gmail.com (T. Gutema), awoketadese3@gmail.com (A. Tadesse)wondadila@gmail.com (W. Adila), manyawqal@gmail.com (W. Shiferaw), geremewbiramo@gmail.com (G. Biramo)

${ }^{*}$ Corresponding author

\section{To cite this article:}

Misgana Mitiku, Mehari G/michael, Tamirat Gutema, Awoke Tadesse, Wondimu Adila, Wondewosen Shiferaw, Geremew Biramo. Identification of Major Crop Production Constraints and Technology Needs in H1 Agro-ecology of Alga PA in South Ari District of South Omo Zone. International Journal of Oil, Gas and Coal Engineering. Vol. 5, No. 5, 2017, pp. 75-79. doi: 10.11648/j.ogce.20170505.12

Received: April 7, 2017; Accepted: April 26, 2017; Published: October 24, 2017

\begin{abstract}
The livelihood of over 93\% of the people of Southern Nation Nationality and peoples Regional state of Ethiopia dependent on agriculture; however, agricultural system in the region is at subsistence level. Much effort has been put to produce or adapt agricultural technologies that would help to boost production and productivity but only few technologies adopt by the end users. Because, technologies might have not be driven from the real need of the end users. A top bottom approach that dominantly centered researchers/ professional attitudes has been fallowed. For the successful research and development, an agro-ecology based evaluation is crucial to know the specific farming system production practices and problems and technology needs of farmers and /or pastoralists. In this line, an assessment study was conducted in H1 agroecology of Alga PA in South Ari district of South Omo zone. The rain fall pattern is bimodal. Major crops grown in the area are Sorghum Maize, Common bean, finger millet, Cassava, Irish Potato, Sweet Potato, Taro, Banana, Coffee, and Peppers.
\end{abstract}

Keywords: Agricultural Problem Identification, Production Constraints, H1 Agro-ecology, Agricultural Technologies

\section{Introduction}

Ethiopia is one of the fastest growing non-oil economy countries in Africa. The country is heavily reliant on agriculture as a main source of employment, income and food security for a vast majority of its population [7]. Agriculture generates $40 \%$ of gross domestic products (GDP) [10], and accounts for 85 and $90 \%$ of total employment and exports, respectively [7].

Agriculture is the most important determinant of Southern Nation Nationality and peoples' Regional state of Ethiopia economy and it will continue to play important role in the overall economy development of the region. The livelihood of over $93 \%$ of the people of the region dependent on it, however, agricultural systems in the region is at subsistence level and food insecurity problem is increasing at shocking rate. Moreover, rapid natural resource degradation is prevalent [2]. Also Agricultural activities in the country as whole have been taking place under widely varying dynamic contexts such as physiography, agro-ecology, climate and soil conditions. The success in the sector is then strongly influenced by topographic settings, degree of human interferences and underlying biophysical features [3] [4].

Economy of Ethiopia largely based on agriculture which accounts for $46.3 \%$ of the gross domestic product, $83.9 \%$ of exports, and $80 \%$ of the labor force in $2006 / 2007$, compared to $44.9 \%, 76.9 \%$ and $80 \%$ in $2002 / 2003$, and agriculture remains the Ethiopian economy's most important sector [9]. Ethiopia has great agricultural potential because of its 
immense areas of fertile land, varied climate, generally sufficient rainfall, and large labor pool.

Agriculture is most important determinant of Southern Nation Nationality and peoples Region economy and it will continue to play the leading role in the overall economy development of the region.

The food insecurity problems in the area caused by complex factors ranging from natural ones such as recurrent drought, degradation of natural resources, lack of appropriate technologies, weak institutional support and lack of alternative employment. The same information also stated by [8]. Also farming practices brought disturbances to the ecosystems particularly on soils by disrupting the stable natural biogeochemical processes of nutrient cycle, causing rapid nutrient depletion [11] and attributing to changes on the landscape characteristics [1] [6].

Therefore, there is a greater need to boost agricultural production and productivity. Over the last five decades, researchers and extension have put much effort to generate improved agricultural production technologies and distribute to the users.

Even though several technologies have been developed, the usual agricultural research and innovation pursued in the past have not been very successful to deliver appropriate technologies to the end users. As a result very few technologies developed previously are adapted by the end users and considerable number of technologies are kept in laboratory without significant contribution to the objective they are designed for. This is due to several factors, of which the important once is usually the critical process by which information is collected at grass root level from farmers and pastoralist to understand their specific farming system, production practices and production problems and their technology need is ignored. A top to bottom approach that dominantly centered researchers/ professional attitudes since long time for both research planning and technology generation.

The technology generated in this way might not address the real problems of the farming community as they were users demand driven and hence the farming community would be passive beneficiary of the new technology. The research approaches have also been blamed for not targeting agroecologies and for disregarding the native technical knowledge's.

At present the regional government has recognized the needs move away from the existing research approach so as to generate and adapt problem solving appropriate technologies centering the real needs of farming community. Accordingly, the existing research approach and process was reviewed and found be lengthy and less effective to deliver appropriate technologies and insufficient to the research customers (Farmers, pastoralist, and private investors). As a result, reengineering the research process is in progress. This progression process is expected to bring a radical, dynamic and rapid change and sustainable development in the agricultural sector through generating, adaptation and deliver of appropriate technologies with in short period of time by cutting-off length steps that adds no values to the customer.

Newly Ethiopia was divided in to 18 major agro-ecological zones and 48 sub-zones based on altitude rainfall and length of the growing period [5]. The research process, one of the vital that often ignored and presently received much attention in the new approach is agro-ecology based assessment. The assessment study is take off for the subsequent research and extension activities and meant to identify agro-ecology based agricultural production constraints and technology needs of the farming community. Hence, this study was conducted in H1 agro-ecology of Alga PA with the following objectives: (1). To describe and understand the nature of the farming system, and production practices, (2). To understand farmers indigenous technical knowledge (3). To analyze and prioritize the major crop production constraints, (4). To identify farmers technology needs and (5). To better understand the existing condition in the H1 agro- ecology and avail information to researchers and development workers and (6). To identify post-harvest handling system.

\section{Methodology}

The study was conducted in Alga PA of South Ari district of South Omo zone. The PA represents H1 agro-ecology. The study was conducted by a multidisciplinary team of researchers and development workers comprising of plant breeder, agronomist, Plant pathologist weed science and food science researcher. The researchers were from Jinka Agricultural Research Center while the development workers are from South Omo and South Ari Agricultural and Rural development office.

Before starting of the study, the study team made short discussion with Agricultural and rural development office (ARD) of South Ari district. Discussion was made to get information with regard to the important preliminary conditions for the study such as assignment of experts for the study team, the representatives of the PA, selection of the informant farmers and awareness created to the farmers of the selected PA and also to the PA administration and development agents working there.

A total of 20 informant farmers of extension groups representing the PAs, mix of variable ages and both sexes were selected by themselves in collaboration with development agent of Alga PA For the purpose of discussion, the farmers were grouped in to two the first group consisting of 10 males and 4 females. The other group formed was the key informants sub-group with six farmers.

Primary data were collected through discussion among the disciplinary based sub-groups and the corresponding farmers sub groups. The discussion was guided by the checklist prepared at regional level and issues raised during discussion were incorporated. Visual observation were also made at farm level.

Upon completion of sub group level discussion, information particularly crop production and production related constraints identified by each sup groups of farmers were summarized together. Then, informants farmers were gathered as one group and summarized series of constraints had been briefed to them and then they ranked the problem by agreement in order of their importance. 

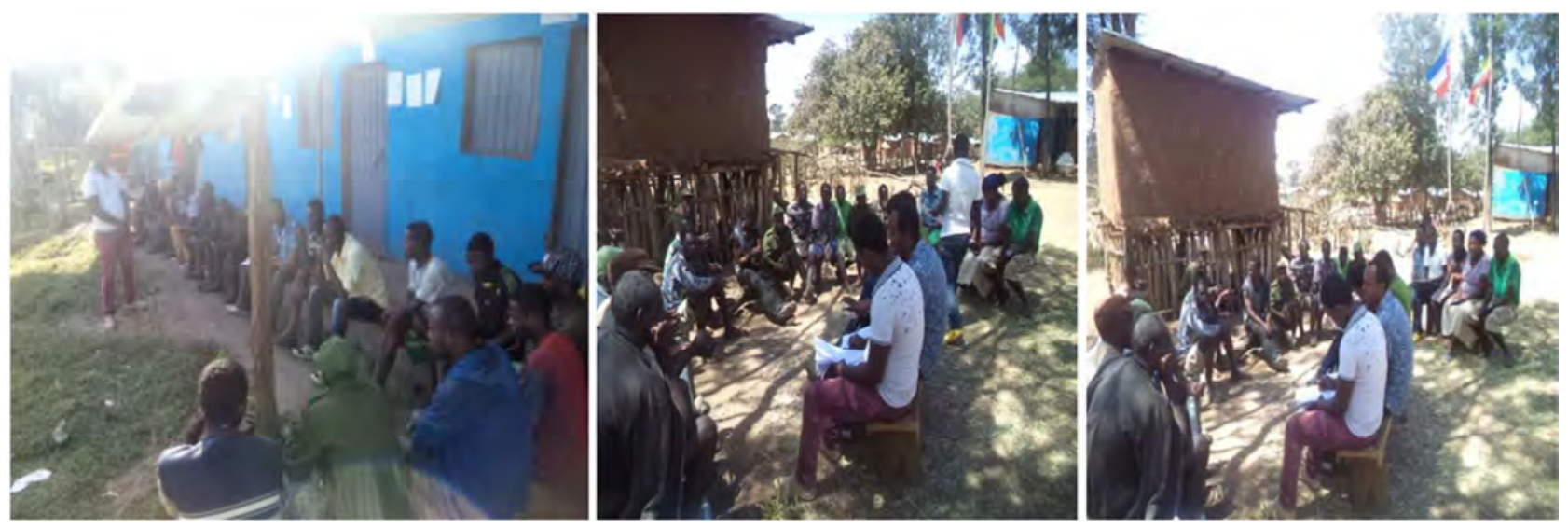

Figure 1. Discussion with farmers.

\section{Result and Discussion}

\subsection{Crop Production}

\subsubsection{Major Crops Cultivated and Cropping System}

The major crops grown in the Alga PA include sorghum, maize, finger millet, common bean, Enset, Cassava, Sweet potato, Irish potato, Taro, Coffee, Pepper, pigeon pea, ground nut, Mango, Avocado and Banana. The PA has two cropping seasons Autumn and Summer. Common cropping systems practiced in PA are sole cropping and intercropping. Farmers grow crops for home consumption, seeds and income generation. As there are diverse farming system in Alga PA, the production problems are also diverse.

Farmers listed series of problems that affects the productivity of the existing crop varieties as army worm and stalk borer on maize and sorghum, head smut on sorghum and maize, ear rot on maize, leaf blight on common bean, bacterial wilt on Enset and Banana, anthracnose on mango and avocado, bird attack on sorghum, erratic rainfall, mole rat attack on Enset. Weevils and rats are storage pest on different crops. In general the key informants strongly emphasized that the major crop production constraint, Storage pest and opening nature maize variety they are using are major production constraints.

Table 1. Crops cultivated in autumn and summer in alga PA.

\begin{tabular}{ll}
\hline Autumn & Summer \\
\hline Sorghum & Maize \\
Maize & Common bean \\
Common bean & Hot pepper \\
Hot Pepper & Sweet potato \\
Sweet potato & Coffee \\
Ground nut & Cassava \\
Irish potato & Mango \\
Finger millet & Avocado \\
\hline
\end{tabular}

Table 2. Local and improved crop varieties in alga PA.

\begin{tabular}{|c|c|c|}
\hline Crops & Improved & Local \\
\hline \multirow{2}{*}{ Maize } & BH-140 & - \\
\hline & Gibe-1 & \\
\hline Common bean & Hawassa dume (High yielder) & Red, Black and Burabure Common bean \\
\hline Sorghum & - & Musri, Akedo, Delge tand dayssa \\
\hline Finger millet & Taddese & Dinet (early matured), Hokesha, Keja, White dagussa, \\
\hline Irish potato & Welayeta & Small and Big tuber size \\
\hline Sweet potato & Aweropa & Metate \\
\hline Hot pepper & - & Hot pepper \\
\hline Chili & - & Chili \\
\hline Cassava & Qulle & Fakelsi \\
\hline Ground nut & Big size & Small size \\
\hline Taro & Yeferenge godere & Dume, Hozake, Chelmes and Aba \\
\hline Mango & Yeferenje mango & - \\
\hline Avocado & Nech and tikur avocado & - \\
\hline Banana & Nech, asmera frenje and ambo banana & Red banana \\
\hline Enset & - & Gena, Selta, Giferik, Orfa, Ontan, Qerta and Qaqet \\
\hline Areal yam & - & Muqerut, Dersheshech and Gersha \\
\hline
\end{tabular}

Note: local varieties are named according to their language. 


\subsubsection{Method of Seed Selection and Maintenance}

According to the interviewed farmers seed selection is done by selecting maize plants with large cobs and big seed size and sorghum having large head at field condition. For common bean seeds are selected after threshing from those plants which have good looking seeds and free from disease/insect pest.

The selected plants in case of maize and sorghum are harvested separately, tied together and hung over smoking places whereas selected plant of haricot bean would be threshed and mixed/ treated with ash in order to protect it from weevils and other storage pest infection.

\subsection{Agronomic Practices}

\subsubsection{Land Preparation}

All farmers use oxen plowing for land preparation. The land is tilled 2-4 times until it gets ready for seed sowing depending on crop types and nature of land. Major constraints of land preparation and planting as mentioned by the key informants are livestock diseases, erratic nature of rainfall, shortage of farm implements and labor.

According to interviewed farmers, the common cropping systems practiced in the Alga PA are mono cropping but previously they use intercropping. Both broadcasting and row planting are practiced in the PA. Sorghum and Finger millet are broadcasted whereas maize and common bean are planted in row. Common bean is planted being mixed with maize. They use a seed rate of $25 \mathrm{~kg} / \mathrm{ha}$ of maize and $96 \mathrm{~kg} / \mathrm{ha}$ of common bean. They do not practice crop rotation.

\subsubsection{Weeds and Weeding}

The major weed species of the PA are 'Gelmma (major problem on finger millet and maize)', 'Ababula', 'Ganaa', 'Stesti (cyprus spp.)', 'Serdo', Akedishi'. Cultural practices such as repeated cultivation and hand weeding are used to control weeds. The first hand weeding in maize is carried out after 15 days of planting fallowed by shilshalow after 35-45 days of planting. For common bean, sorghum and finger millet hand weeding is carried out only one time after 30 days of planting.

\subsubsection{Fertilizer Use}

Farmers reported that they apply urea and DAP fertilizers only for maize production in the locality. Both types of fertilizer are applied at the rate of $100 \mathrm{~kg} / \mathrm{ha}$ each. But the time of application is different. Both DAP and UREA are applied at the time of planting if sufficient rainfall is exist during planting but if no sufficient rainfall they use split application for UREA i.e. 50\% during planting and the rest $50 \%$ after 45 days.

\subsubsection{Farm Implements/Mechanization}

Various traditional implements are used in the PA for different activities. The major implements include 'Wolle', 'Boyira' 'Gosha' axe and plow. According to interviewed farmers 'Gosha' is used for cultivation, 'Boyira' is used for digging and cultivation whereas 'Wolli' for cutting grass and clearing. These implements are conventional, less effective, time consuming and laborious. The sources of farm implements are local markets.

Table 3. Farm operation calendar of some crops in alga PA.

\begin{tabular}{llll}
\hline Crop & Land preparation & Sowing/planting & Harvesting \\
\hline Sorghum & January & February & July \\
Maize & January (Autumn) & February first to March 10 & June to July \\
& June (Summer) & July, 29 to August 30 & December to January \\
Common bean & January (Autumn) & February first to March 10 & June to July \\
Finger millet & June (Summer) & July, 29 to August 30 & December to January \\
\hline
\end{tabular}

\subsubsection{Storage, Processing and Marketing}

Farmers in Alga PA store their crop products mainly in granary made of wood /bamboo which leads to entrance of storage pest (weevil and rats). Rats and weevils are the common storage pests in the locality. With regard to marketing, the farmers revealed that the PA is potential for diverse crop production they have surplus production for sale.

Common bean and maize are sold in large quantity for merchants in local as well as in urban market at Jinka and key Afer town. Maize is sold in large quantity to earn money to cover input price. The farmers in the area utilize root and tuber crops in the form of boiled form but in case of cassava in both forms (Boiled and powdery form) and sold them to pay fertilizer cost and taxes. Maize is susceptible to weevil and usually sold immediately after harvesting as result the farmers are forced to sell it in cheap price. Traditional way of harvesting leads to injury of the fruit such as Mango and
Avocado as a result the price of the product decreases.

\section{Conclusion and Recommendation}

The livelihood of over $93 \%$ of the people of Southern Nation Nationality and peoples Regional state of Ethiopia dependent on agriculture; however, agricultural system in the region is at subsistence level. Much effort has been put to produce or adapt agricultural technologies that would help to boost production and productivity but only few technologies adopt by the end users. There are a number of production problem which occurs at different section of production like in cropping system, method of seed selection and maintenance, land preparation, weeds and weeding, fertilizer use, storage, processing and marketing of the products in the studied areas. Minimizing pre and postharvest losses of cereals and horticultural perishables crops is a very effective way of reducing the area needed for production and/or 
increasing food availability. Solving the pre and postharvest food distribution problems in a given area will require cooperation and effective communication among all the research, extension, and industry personnel involved. So, there should be strong relationship between research, extension, and industry personnel involved for alleviating these production, marketing and technological problems. Finally adoption of improved technologies which helps in production and marketing of these agricultural products are very essential in the studied area.

\section{References}

[1] Alemu B (2015) The effect of land use land cover change on land degradation in the highlands of Ethiopia. J Env Earth Sci 5: $1-12$.

[2] Almekinders SJM, Elings A (2001). collaboration, crop improvement in perspective. Euphytica. 122: 425 -438. Doi: 10.1023/A: 10779687875 .

[3] Chamberlin J, Emily S (2011) Ethiopian agriculture: a dynamic geographic perspective. Development Strategy and Governance Division, International Food Policy Research Institute, Ethiopia Strategy Support Program II, Ethiopia.

[4] Diwediga B, Wala K, Folega F, Dourma M, Woegan YA, Akpagana K, Le QB (2015) Biophysical and anthropogenous determinants of landscape Patterns and degradation of plant communities in Mo Hilly Basin (Togo). Ecol Eng 85: 132 143.

[5] Ethiopian Institute of Agricultural Research website. (Accessed 4 February 2009).

[6] Gebreselassie Y, Anemut F, Addisu S (2015) The effects of land use types, management practices and slope classes on selected soil physico-chemical properties in Zikre watershed, North-Western Ethiopia. Springer Open J Env Sys Res 4: 1-7.

[7] IFDC (International Fertilizer Development Center) (2012) Ethiopian fertilizer assessment. IFDC in support of African Fertilizer and Agribusiness Partnership.

[8] Matous. P. Y. Tado (2013). Role of extension and ethnoreligious network in acceptance of resource conserving agricultural resources among Ethiopian farmers, International journal of agricultural sustainability. 11 (4): 301-316.

[9] The Federal Republic of Ethiopia: Selected Issues Series International Ministry Fund Country Report No. 08/259, pp. 5, 26.

[10] UNDP (United Nations Development Programme) Ethiopia (2014) Quarterly economic brief: third quarter. http://www.et.undp.org/content/dam/ ethiopia/docs/Economic\%20 Brief-\%20Third\%20Quarter2014.pdf. 2014. Accessed 19 Nov 2016.

[11] Yengoh GT (2012) Determinants of yield differences in smallscale food crop farming systems in Cameroon. Agric Food Secur 2012 (1): 19. 